\title{
iPLA $A_{2} \beta$ Knockout Mouse, a Genetic Model for Progressive Human Motor Disorders, Develops Age-Related Neuropathology
}

\author{
Helene Blanchard $\cdot$ Ameer Y. Taha \\ Yewon Cheon $\cdot$ Hyung-Wook Kim . \\ John Turk $\cdot$ Stanley I. Rapoport
}

Received: 18 November 2013/Revised: 23 April 2014/Accepted: 22 May 2014/Published online: 12 June 2014

(C) Springer Science+Business Media New York (outside the USA) 2014

\begin{abstract}
Calcium-independent phospholipase $\mathrm{A}_{2}$ group VIa (iPLA ${ }_{2} \beta$ ) preferentially releases docosahexaenoic acid (DHA) from the $s n-2$ position of phospholipids. Mutations of its gene, PLA2G6, are found in patients with several progressive motor disorders, including Parkinson disease. At 4 months, PLA2G6 knockout mice (iPLA ${ }_{2} \beta^{-1-}$ ) show minimal neuropathology but altered brain DHA metabolism. By 1 year, they develop motor disturbances, cerebellar neuronal loss, and striatal $\alpha$-synuclein accumulation. We hypothesized that older iPLA $\beta^{-1-}$ mice also would exhibit inflammatory and other neuropathological changes. Real-time polymerase chain reaction and Western blotting were performed on whole brain homogenate from 15 to 20-month old male iPLA $\beta^{-/-}$or wild-type (WT) mice. These older iPLA $_{2} \beta^{-1-}$ mice compared with WT showed molecular evidence of microglial (CD-11b, iNOS) and astrocytic (glial fibrillary acidic protein) activation, disturbed expression of enzymes involved in arachidonic acid metabolism, loss of neuroprotective brain derived neurotrophic factor, and accumulation of cytokine TNF- $\alpha$
\end{abstract}

H. Blanchard $(\bowtie) \cdot$ A. Y. Taha · Y. Cheon · H.-W. Kim · S. I. Rapoport

Brain Physiology and Metabolism Section, Laboratory of Neurosciences, National Institute on Aging, National Institutes of Health, Bldg. 9, Room 1S126, 9000 Rockville Pike, Bethesda, MD 20892, USA

e-mail: helene.blanchard@nih.gov

H.-W. Kim

College of Life Sciences, Sejong University, 98 Gunja-dong, Gwangjin-Gu, Seoul 143-747, Korea

J. Turk

Division of Endocrinology, Medicine Department Metabolism and Lipid Research, Washington University School of Medicine, St. Louis, MO 63110, USA messenger ribonucleic acid, consistent with neuroinflammatory pathology. There was no evidence of synaptic loss, of reduced expression of dopamine active reuptake transporter, or of accumulation of the Parkinson disease markers Parkin or Pink1. iPLA $2 \gamma$ expression was unchanged. iPLA $_{2} \beta$ deficient mice show evidence of neuroinflammation and associated neuropathology with motor dysfunction in later life. These pathological biomarkers could be used to assess efficacy of dietary intervention, antioxidants or other therapies on disease progression in this mouse model of progressive human motor diseases associated with a PLA2G6 mutation.

Keywords Calcium-independent phospholipase A2 $\left(\mathrm{iPLA}_{2} \beta\right)$ knockout · Brain · Parkinson disease . Arachidonic and docosahexaenoic acid · Motor disturbances · Neuropathology

\section{Introduction}

In vertebrates, the polyunsaturated fatty acid (PUFA) docosahexaenoic acid (DHA, 22:6n-3) is thought to play antioxidant, neuroprotective, and neurotransmission roles in brain [1-4]. DHA must be obtained directly from the diet or by liver synthesis from its dietary essential precursor, $\alpha$-linolenic acid ( $\alpha$-LNA, 18:3 n-3) [5]. It is found in high concentrations in the $s n-2$ position of brain membrane phospholipids, from where it can be released preferentially by a calcium-independent phospholipase $A_{2}$, iPLA $_{2} \beta$ or iPLA $2 \gamma[6,7]$.

iPLA $_{2} \beta$ accounts for $70 \%$ of cytosolic PLA $_{2}$ activity in rat brain $[6,8]$. Mutations in its gene, PLA2G6, occur in infantile neuroaxonal dystrophy (INAD) [9, 10], neurodegeneration with brain iron accumulation (NBIA) [10, 11], 
early-onset dystonia-parkinsonism [12-14], and Parkinson disease [15]. iPLA ${ }_{2} \beta$ knockout mice have been developed to understand the consequences of these mutations [16, 17].

iPLA $_{2} \beta$ plays a role in motor behavior, since injection of the $\mathrm{iPLA}_{2} \beta$ inhibitor bromoenol lactone (BEL) into the rat striatum, thalamus, or motor cortex produces chewing movements [18]. Furthermore, $\mathrm{iPLA}_{2} \beta^{-1-}$ mice exhibit age-dependent motor dysfunction associated with axonal degeneration and spheroids in the central nervous system by 1 year of age $[16,19]$. Similar axonal swelling with spheroids occurs in the central and peripheral nervous systems of INAD and NBIA patients. Thirteen month-old iPLA $_{2} \beta^{-1-}$ mice also show cerebellar atrophy with Purkinje cell loss, increased levels of inflammatory cytokines, glial cell activation, and striatal accumulation of $\alpha$-synuclein $[16,20]$.

To characterize progressive age-related neuropathology in $\mathrm{iPLA}_{2} \mathrm{\beta}^{-1-}$ mice, we first studied brain PUFA metabolism in 4-month old mice with normal motor function and minimal brain spheroid accumulation [4, 21]. Compared to wild-type (WT) controls, these mice exhibited disturbances in brain DHA metabolism that included reduced esterified brain DHA concentration in ethanolamine and serine glycerophospholipids, reduced DHA incorporation rate from plasma into brain phospholipids at rest or during cholinergic activation, and disturbed fatty acid concentrations in lysophospholipids. In addition, their brains showed increased expression of enzymes involved in arachidonic acid (AA, 20:4n-6) metabolism, including cytosolic $\mathrm{CPLA}_{2}-\mathrm{IV} \alpha\left(\mathrm{CPLA}_{2} \alpha\right)$, secretory $\mathrm{sPLA}_{2}-\mathrm{V}$ and cyclooxygenase (COX)-2 [8, 22].

In the present follow-up study, we measured expression of a number of brain parameters in 15 to 20 -month old iPLA $\beta^{-l-}$ mice and in WT mice. These included: (1) enzymes involved in AA metabolism $\left[\mathrm{CPLA}_{2} \alpha, \mathrm{sPLA}_{2}-\mathrm{V}, \mathrm{COX}-2\right.$, COX-1, and microsomal prostaglandin synthase (mPGES) [22] ]; (2) enzymes involved in DHA metabolism [acyl-CoA synthetase (Acsl)-6, membrane-bound $O$-acyltransferase (MBOAT)-7, acyl-CoA:lysophosphatidylethanolamine acyltransferase (LPEAT)-2, and 15-lipoxygenase (15-LOX)]; (3) inflammatory cytokines [tumor necrosis factor (TNF)- $\alpha$ and interleukin (IL)-1 $\beta$ ]; (4) markers of microglial and astrocytic activation $[\mathrm{CD} 11 \mathrm{~b}$, glial fibrillary acidic protein (GFAP), and inducible nitrite oxide synthase (iNOS)]; (5) presynaptic synaptophysin, postsynaptic drebrin and postsynaptic density protein (PSD-95); (6) brain derived neurotrophic factor (BDNF); and 7) Parkinson disease markers [dopamine active reuptake transporter (DAT), $\alpha$-synuclein, PTEN induced kinase 1 (Pink1) and Parkin].

An abstract of part of this work has been published (Society for Neuroscience Meeting, New Orleans, LA, 2012).

\section{Materials and Methods}

Animals

Experiments were conducted in accord with the National Institutes of Health guidelines for the Animal Care and Use Committee (Publication no. 86-23) and followed a protocol approved by the Animal Care and Use Committee of the Eunice Kennedy Shriver National Institute of Child Health and Human Development. Male iPLA ${ }_{2} \beta^{-/-}$mice and their WT littermates [23] were housed in an animal facility having regulated temperature, humidity and light cycle until they reached 15-20 months of age. They had free access to water and to a diet (PicoLab ${ }^{\circledR}$ Rodent Diet 20, 5053, LabDiet, Richmond, IN) containing (as \% total fatty acid): $20.0 \%$ saturated, $22.2 \%$ monounsaturated, $47.7 \%$ linoleic acid, $5.1 \%$ linolenic acid, $0.1 \%$ AA, $0.2 \%$ eicosapentaenoic acid and $0.9 \%$ DHA. Mice $(n=8$ per group) were asphyxiated by $\mathrm{CO}_{2}$ inhalation and decapitated, and their brains were rapidly excised and frozen in 2-methylbutane at $-50{ }^{\circ} \mathrm{C}$ and stored at $-80{ }^{\circ} \mathrm{C}$ for subsequent analyses.

\section{Gene Expression}

Half brains were homogenized with an Ultraturax homogenizer (IKA Works, Wilmington, DE) in QIAzol lysis reagent (Qiagen, Valencia, CA) and mRNA was isolated with a phenol-chloroform extraction method using the RNeasy Lipid tissue kit (Qiagen). Total mRNA was reverse-transcribed to cDNA according to the manufacturer's instructions with a high capacity cDNA Archive kit (Applied Biosystems, Carlsbad, CA). Gene expression was determined by real time-polymerase chain reaction (RT-PCR) using the Taqman ${ }^{\circledR}$ Universal PCR Mastermix and specific Taqman ${ }^{\circledR}$ primers and probe (Applied Biosystems). The PCR reaction was performed in duplicate, using ABI Prism 7000 sequence detection system (Applied Biosystems) as follows: $2 \mathrm{~min}$ at $50{ }^{\circ} \mathrm{C}, 5 \mathrm{~min}$ at $95{ }^{\circ} \mathrm{C}, 40$ cycles of $10 \mathrm{~s}$ at $95^{\circ} \mathrm{C}$, and $1 \mathrm{~min}$ at $60{ }^{\circ} \mathrm{C}$. Relative gene expression was determined using the $\Delta \Delta \mathrm{Ct}$ method, using the $18 \mathrm{~S}$ gene expression for normalization.

\section{Protein Extraction}

Half-brains were homogenized in a buffer containing 10 mM HEPES, pH 7.5, 1 mM EDTA, $0.34 \mathrm{M}$ sucrose and protease inhibitors (Complete EDTA-free, Roche Applied Science, Indianapolis, IN), using a Dounce glass homogenizer (Thomas Scientific, Swedesboro, NJ). After ultracentrifugation $\left(100,000 \mathrm{~g}, 1 \mathrm{~h}, 4{ }^{\circ} \mathrm{C}\right)$, the supernatant was used as the cytosolic fraction. The pellet was resuspended in Tris $20 \mathrm{mM}$, pH 7.4 containing $0.2 \%$ Triton X-100 for 
$1 \mathrm{~h}$ at $4{ }^{\circ} \mathrm{C}$ under agitation. The sample was centrifuged $\left(100,000 \mathrm{~g}, 1 \mathrm{~h}, 4^{\circ} \mathrm{C}\right)$ and the resulting supernatant contained the membrane fraction. Protein concentrations in the cytosolic and membrane fractions were determined with a Bradford assay [24] and samples were stored at $-80{ }^{\circ} \mathrm{C}$ until analyzed.

\section{Protein Analysis}

Cytosolic or membrane proteins $(20 \mu \mathrm{g})$ were separated by SDS-PAGE in 4-20\% Tris- $\mathrm{HCl}$ polyacrylamide gels (BioRad, Hercules, CA) and transferred on a nitrocellulose membrane (Bio-Rad) for immunoblotting. Membranes were blocked for $90 \mathrm{~min}$ at room temperature with a caseinbased blocking buffer (Sigma Aldrich, St Louis, MO) before incubation overnight at $4{ }^{\circ} \mathrm{C}$ with primary antibodies. Cytosolic proteins were probed with specific antibodies for $\mathrm{cPLA}_{2} \alpha$ (1:500), $\mathrm{sPLA}_{2}-\mathrm{V}$ (1:500), iNOS (1:200), COX1 (1:200), Il-1 $\beta$ (1:200), 15-LOX (1:200), drebrin (1:500) and Pink1 (1:200) (Santa Cruz Biotechnology, Santa Cruz, CA), for COX-2 (1:200), GFAP (1:50,000), PSD-95 $(1: 1,000)$, BDNF $(1: 1,000)$ (AbCam, Cambridge, MA), for Acsl-6 (Novus Biochemical, Littleton, MO) or for $\alpha$-synuclein (1:5,000) (Cell signaling, Danvers, MA). Membrane fractions were blotted with antibodies targeting phosphorylated-cPLA $2 \alpha$ (P- cPLA $\left._{2} \alpha\right)$ (1:500, Santa Cruz), mPGES (1:500, Cayman Chemical, Ann Arbor, MI), CD11b (1:500), synaptophysin (1:15,000) (AbCam), MBOAT7 (Aviva Systems Biology, San Diego, CA), LPEAT2 $(1: 1,500)$ (ProteinTech, Chicago, IL) and DAT $(1: 1,000)$ (Millipore, Billerica, MA). All samples were probed with a $\beta$-actin antibody (Sigma Aldrich). Parkin expression was determined in the cytosol and membrane fractions $(1: 2,000$, AbCam). Membranes then were incubated for $90 \mathrm{~min}$ at room temperature with the appropriate horseradish peroxidase-conjugated secondary antibodies (Bio-Rad), and peroxidase activity was determined by chemiluminescence using the SuperSignal West Pico reagents (Thermo Fisher Scientific, Rockford, IL). Relative protein expression was determined after normalization with the $\beta$-actin expression using ImageJ software [25]. TNF- $\alpha$ protein was quantified from $100 \mu \mathrm{g}$ of brain cytosolic extract using an enzymelinked immunosorbent assay (ELISA) method according to the manufacturer's instruction (Thermo Fisher Scientific).

\section{Statistical Analyses}

Data are expressed as mean $\pm \operatorname{SEM}(\mathrm{n}=7-8$ per group). A two-tailed, unpaired $t$ test using GraphPad Prism 5 software (GraphPad Software, Inc., La Jolla, CA) was used to determine statistical significance, when $P<0.05$. Cohen's $d$ effect size was used to interpret differences between the means when the $P$ value was between 0.05 and 0.2 , since this

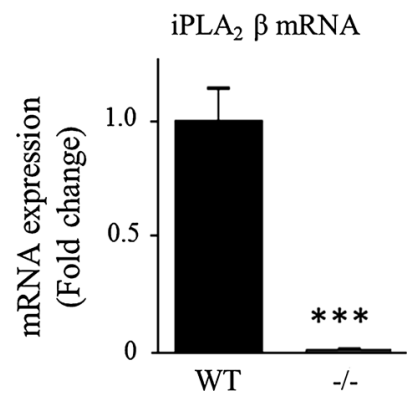

Fig. 1 mRNA expression of $\mathrm{PLA}_{2} \beta$ in WT and $\mathrm{PLAA}_{2} \beta^{-1-}$ mice. mRNA was quantified in duplicate with Taqman ${ }^{\circledR}$ RT-PCR using the $\Delta \Delta \mathrm{Ct}$ method and normalization to $18 \mathrm{~S}$ expression. Results are expressed as mean \pm SEM $(\mathrm{n}=8)$. $* * * P<0.001$ ( $t$ test $)$

suggested increased risk of type II error associated with the small number of animals available for the study. An effect size is considered small if $0.3<d<0.5$, medium if 0.5 $<d<0.8$ and high if $d>0.8$ [26]. We considered effect sizes greater than 0.5 likely to be significant. Outliers were identified using Grubb's test and removed from the statistical analysis.

\section{Results}

\section{Brain AA and DHA Metabolism}

$\mathrm{iPLA}_{2} \beta$ protein expression was not measured in this study but iPLA $2 \beta$ deficiency was confirmed in the iPLA ${ }_{2} \beta^{-/-}$mice by the virtual absence of brain iPLA $2 \beta$ mRNA compared to WT mice $(P<0.001$; Fig. 1$)$, whereas the iPLA $2 \gamma$ mRNA level did not differ between genotypes (Fig. 2c). cPLA $_{2} \alpha$ mRNA and protein levels were similar between groups, but the protein level of the activated phosphorylated form of $\mathrm{cPLA}_{2} \alpha$ in the membrane fraction was significantly higher for $\mathrm{iPLA}_{2} \beta^{-/-}$compared to WT mice (51\%, $P=0.04$ ) (Fig. 2a). Although sPLA $2-\mathrm{V}$ mRNA also was higher (64 \%, $P=0.02$ ), sPLA ${ }_{2}-\mathrm{V}$ protein did not differ significantly between genotypes (Fig. 2b). COX-1 mRNA and protein and COX-2 mRNA also did not differ between genotypes (Fig. 3a), while COX-2 protein was reduced in $\mathrm{iPLA}_{2} \beta^{-/-}$ mice (12\%, $P=0.03$ ) (Fig. 3b). Brain mPGES mRNA was significantly higher in $\mathrm{iPLA}_{2} \beta^{-/-}$mice, but mPGES protein did not differ between genotypes (Fig. 3c). Protein levels of Acsl-6, MBOAT7, LPEAT2 and 15-LOX also did not differ between $\mathrm{iPLA}_{2} \beta^{-l-}$ and WT mice (Fig. 4).

Neuroinflammation and Synaptic Loss

TNF- $\alpha$ mRNA was increased 2.1 -fold $(P<0.001)$ in $\mathrm{iPLA}_{2} \beta^{-1-}$ mice compared to WT, but TNF- $\alpha$ protein levels were similar in both groups (Fig. 5a), as were levels of IL-1 $\beta$ mRNA and protein (Fig. 5b). iNOS mRNA and 

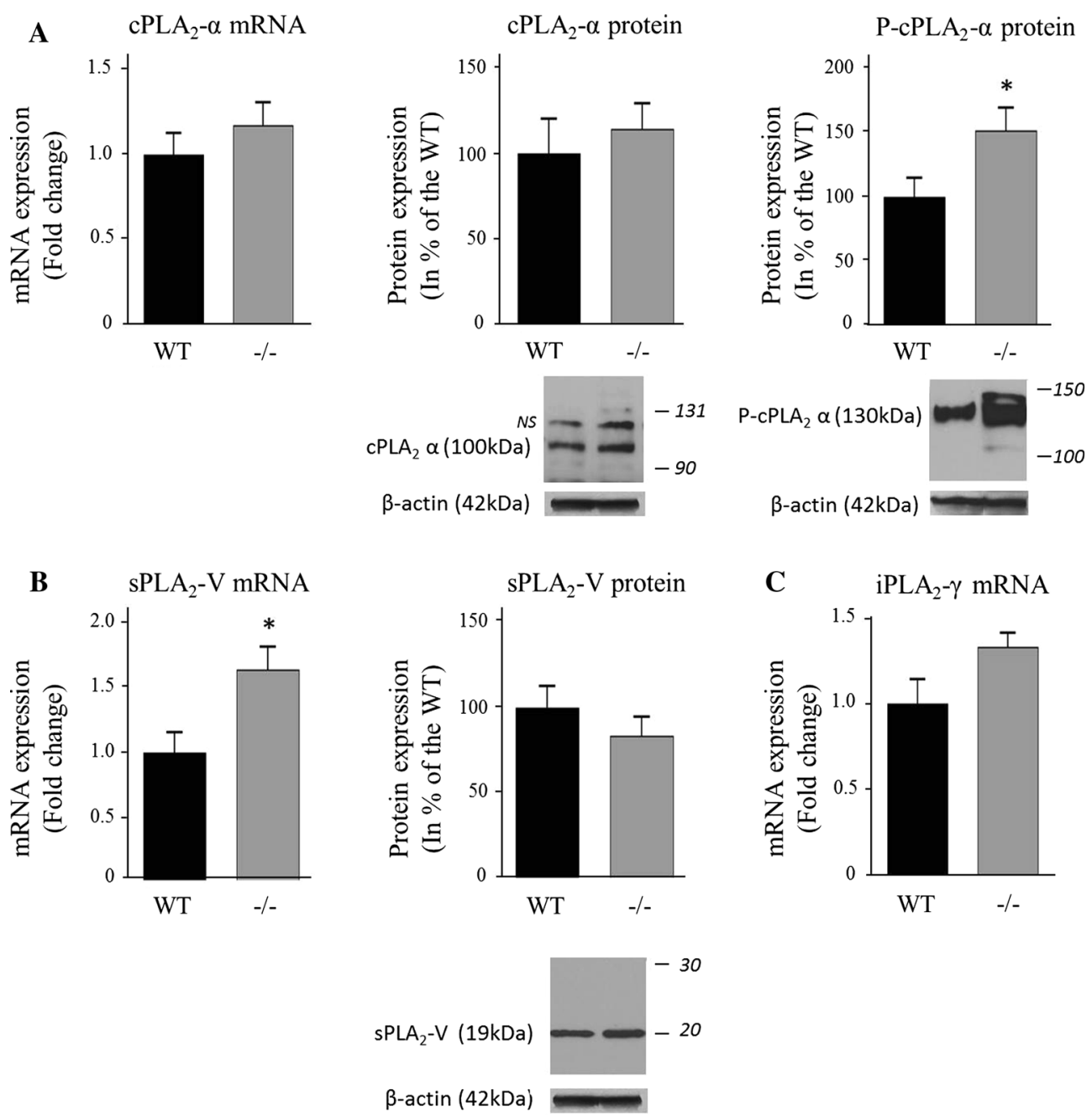

Fig. 2 Expression of $\mathrm{cPLA}_{2} \alpha(\mathbf{a}), \mathrm{sPLA}_{2}-\mathrm{V}(\mathbf{b})$ and $\mathrm{iPLA}_{2} \gamma$ in WT and iPLA $_{2} \beta^{-1-}$ mice. mRNA was quantified in duplicate with Taqman ${ }^{\circledR}$ RT-PCR using the $\Delta \Delta \mathrm{Ct}$ method and normalization to $18 S$ expression. Results are expressed as mean \pm SEM $(n=8) \cdot \operatorname{cPLA}_{2} \alpha$ and $\mathrm{SPLA}_{2} \mathrm{~V}$ protein was measured in brain cytosol and P-cPLA $2 \alpha$ was quantified in the membrane fraction by Western blot. Results are

normalized to $\beta$-actin expression (representative immunoblot is displayed) and expressed as \% of the WT mice as mean \pm SEM $\left(\mathrm{n}=8\right.$, except $\mathrm{n}=7$ for P-cPLA 2 in iPLA $_{2} \beta^{-1-}$ because an outlier value of 7.4 was removed). Numbers in italics indicate molecular weight markers (in $\mathrm{kDa}$ ), $N S$ : non-specific band. $* P<0.05$ ( $t$-test)

protein did not differ significantly on $t$ tests $(P=0.07$ and 0.14 respectively), but their effect sizes measured as Cohen's $d$ were large, 0.99 and 0.98 respectively (Fig. 5c).

CD11b mRNA and protein levels were significantly higher in $\mathrm{PLLA}_{2} \mathrm{\beta}^{-1-}$ mice compared to WT (60 and $30 \%$, $P<0.05$, respectively) (Fig. 6a), suggesting microglial activation [27]. GFAP mRNA was elevated 2.2-fold $(P<0.01)$ in iPLA $\beta_{2} \beta^{-/-}$mice, but its protein level did not differ significantly between genotypes on $t$-tests $(P=0.19)$; nevertheless, Cohen's $d$ test suggested a modest increase $(d=0.68)$ in iPLA ${ }_{2} \beta^{-/-}$mice (Fig. 6b). Protein levels of pre-synaptic synaptophysin and post-synaptic drebrin and PSD95 did not differ between genotypes (Fig. 6c), while BDNF protein was reduced in $\mathrm{iPLA}_{2} \beta^{-1-}$ mice $(22 \%$, $P=0.01$ ) (Fig. 6d).

\section{Parkinson Disease Markers}

Protein levels of both reduced DAT $(50 \mathrm{kDa})$ and nonreduced DAT (75 $\mathrm{kDa})$ did not differ between $\mathrm{iPLA}_{2} \beta^{-1-}$ mice and WT mice (Fig. 7). Alpha-synuclein mRNA was significantly higher (53\%,P $=0.01$ ), but $\alpha$-synuclein protein (Fig. 8a), Pink1 (Fig. 8b) and Parkin (Fig. 8c) mRNA and protein did not differ between groups.

\section{Discussion}

These results indicate that long-term disruption of brain DHA metabolism in aged mice due to the absence of PLA2G6 results in microglial and astrocytic activation, 
Fig. 3 Expression of COX-2

(a), COX-1 (b) and mPGES

(c) in WT and iPLA $_{2} \beta^{-1-}$ mice.

mRNA was quantified in

duplicate with Taqman ${ }^{\circledR}$ RT-

PCR using the $\Delta \Delta \mathrm{Ct}$ method

and normalization to $18 \mathrm{~S}$

expression. Results are

expressed as mean \pm SEM

$(\mathrm{n}=8)$. COX-2, COX-1 were

measured in brain cytosol and

mPGES in the membrane

fraction by western blot and

normalized to $\beta$-actin

expression (representative

immunoblot is displayed).

Results are expressed as \% of

the WT mice as mean \pm SEM

( $\mathrm{n}=8$, except $\mathrm{n}=7$ for COX-

1 protein in WT due to an

outlier value of $198^{-1-}$ ).

Numbers in italics indicate molecular weight markers (in $\mathrm{kDa}) . * P<0.05, * * P<0.01$ ( $t$ test)
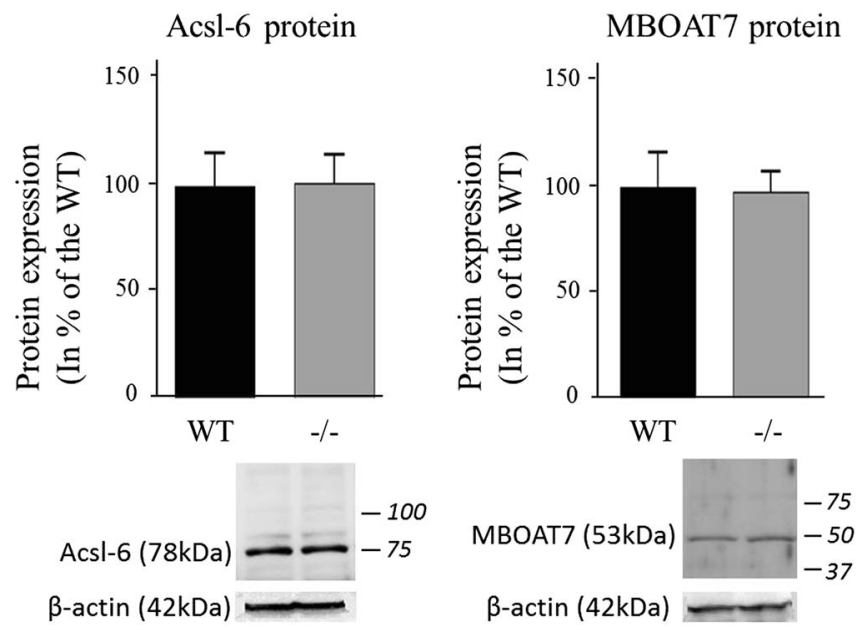

Fig. 4 Expression of brain DHA-metabolizing enzymes in WT and ${ }_{\text {iPLA }} \beta^{-1-}$ mice. Acsl- 6 and 15-LOX protein was measured in brain cytosol, MBOAT7 and LPEAT2 in the membrane fraction by Western blot and normalized to $\beta$-actin expression (representative
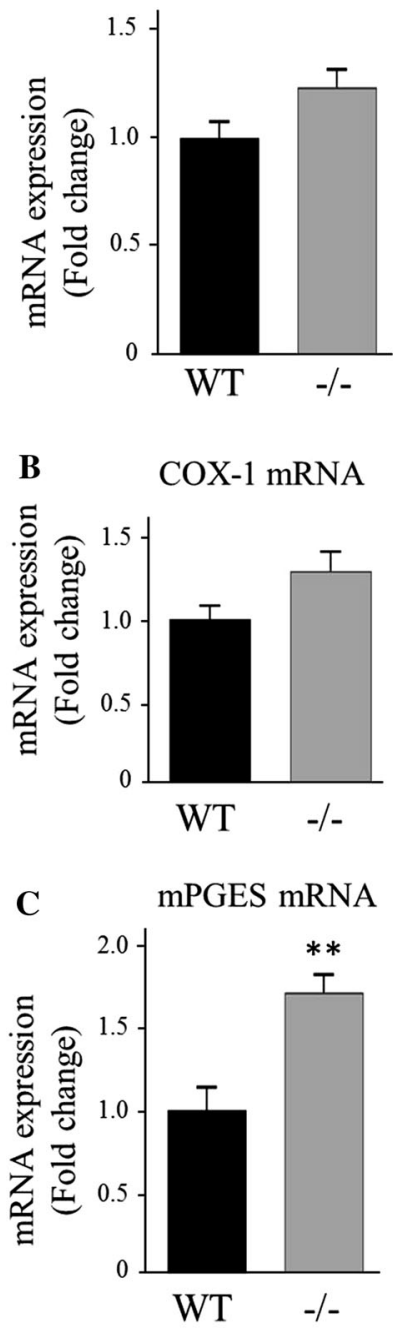

\section{A $\quad$ COX-2 mRNA \\ COX-2 protein}
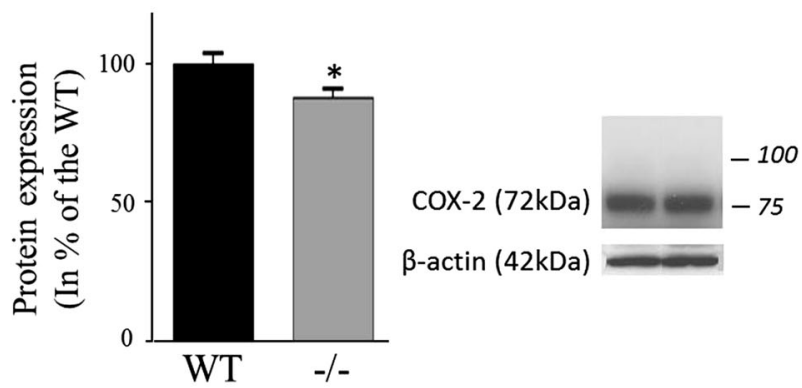

$\beta$-actin (42kDa)
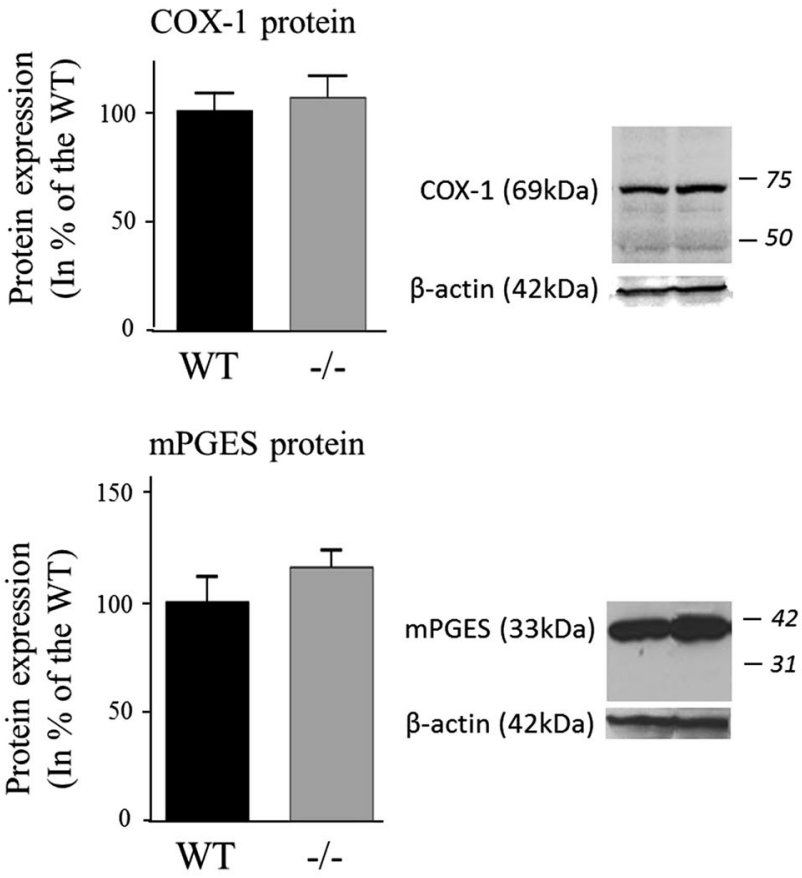

$\beta$-actin (42kDa)

$\beta-\operatorname{actin}(42 \mathrm{kDa})$

B-actin (42k)
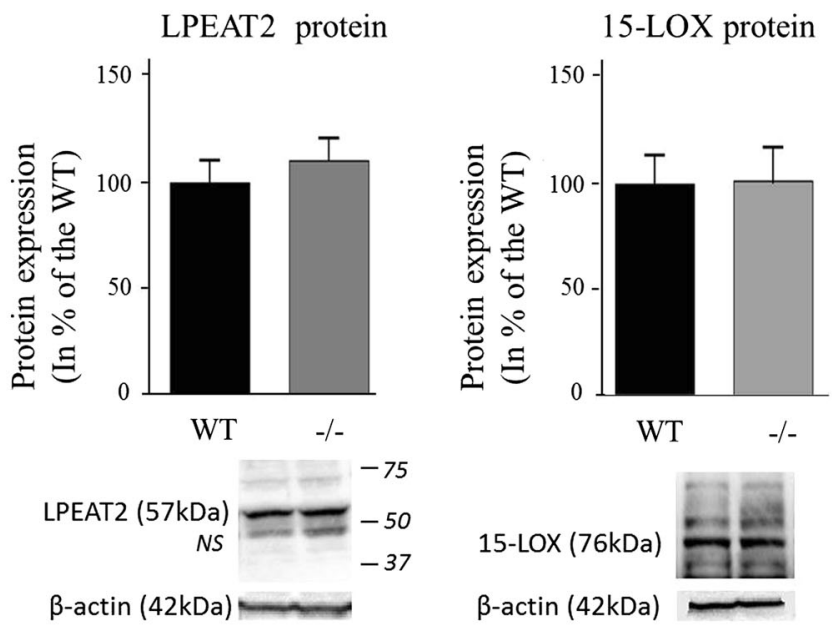

immunoblot is displayed). Results are expressed as \% of the WT mice as mean \pm SEM $(\mathrm{n}=8)$. Numbers in italics indicate molecular weight markers (in $\mathrm{kDa}$ ), $N S$ non-specific band 

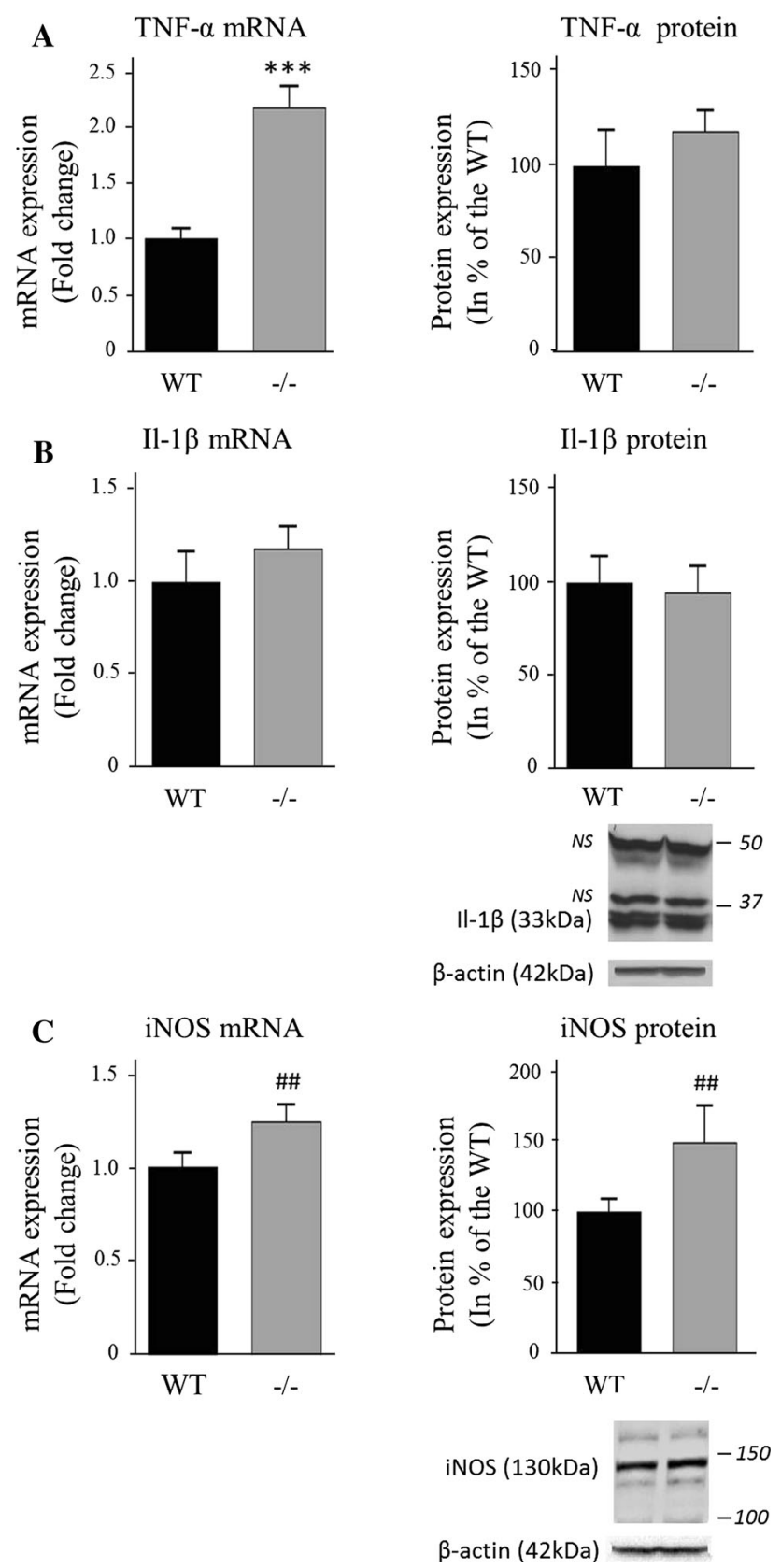

Fig. 5 Expression of the pro-inflammatory cytokines TNF- $\alpha$ (a) and Il-1 $\beta$ (b) and the iNOS (c) in WT and iPLA $\beta^{-1-}$ mice. mRNA was quantified in duplicate with Taqman ${ }^{\circledR}$ RT-PCR using the $\Delta \Delta \mathrm{Ct}$ method and normalization to $18 \mathrm{~S}$ expression. Results are expressed as mean \pm SEM $(n=8)$. An ELISA assay was used to quantify cytosolic TNF- $\alpha$. Il-1 $\beta$ and iNOS protein was measured in brain cytosol by Western blot and normalized to $\beta$-actin expression (representative immunoblot is displayed). Results are expressed as $\%$ of the WT mice as mean \pm SEM $(n=8$, iNOS $\mathrm{n}=6$ for WT and $\mathrm{n}=7$ for $\mathrm{PLAA}_{2}^{-/-}$due to unquantifiable signal). Numbers in italics indicate molecular weight markers (in $\mathrm{kDa}$ ), $N S$ non-specific band. $* * * P<0.001$ ( $t$ test) and ${ }^{\# \#} d>0.8$ (Cohen's $d$ test)

increased TNF- $\alpha$ and $\alpha$-synuclein, disturbed expression of enzymes involved in AA metabolism, and a reduced BDNF level. The results also show that $\mathrm{iPLA}_{2} \beta$ and $\mathrm{iPLA}_{2} \gamma$ play independent roles in brain, because brain iPLA $2 \gamma$ expression was unchanged iPLA $\beta_{2} \beta^{-1-}$ mice. The large effect sizes of increments in iNOS mRNA and protein and in TNF- $\alpha$ mRNA (and protein by Cohen's $d$ ), and increased CD11b mRNA and protein, suggest microglial activation by age 15-20 months [27]. Motor function was not assessed in the present study, but these neuropathological markers might be associated with appearance of age-dependent motor abnormalities in iPLA $\beta_{2} \beta^{-/-}$mice reported by others $[16,19]$. The lack of change in IL-1 $\beta$ levels suggests that full-blown global inflammation is not reached at this age and may require more time to evolve. On the other hand, Purkinje cell loss, glial cell activation and elevated TNF- $\alpha$ and IL- $1 \beta$ expression have been reported in the cerebellum of iPLA $\beta^{-/-}$mice at age 13 months [20].

The many late-appearing neuropathological changes in the iPLA $_{2} \beta^{-1-}$ mice suggest that early defective DHA metabolism can contribute to human diseases that result from PLA2G6 mutations, such as INAD, neurodegeneration with brain iron accumulation, and early onset-dystonia parkinsonism (see 'Introduction'). Thus, this mouse model might be used to develop therapy for these diseases. Since $\mathrm{iPLA}_{2} \beta$ has an anti-oxidant function that protects mitochondria from peroxidation damage [17], one therapeutic approach with the model would be to administer antioxidants, as recommended for Parkinson disease [17, 28, 29]. Feeding DHA has been considered in this regard [2], but the mice already were on a high DHA diet. On the other hand, an AA-free diet low in linoleic acid (18:2n-6) might be help to dampen the upregulated AA-metabolizing enzymes in the iPLA $_{2} \beta^{-/-}$mouse brain [30-32].

Unesterified DHA is preferentially acylated by Acsl-6 to DHA-CoA [33], which can be reacylated into a lysophospholipid by an acyl-CoA lysophospholipid acyltransferase [34]. Within this latter enzyme family, we analyzed expression of MBOAT7, which recognizes AA-CoA as a substrate [35], although its activity toward DHA-CoA remains to be tested. We also measured LPEAT2, which preferentially acylates ethanolamine glycerophospholipid enriched with DHA [36, 37]. The incorporation rate of unesterified DHA into brain ethanolamine glycerophospholipids and their DHA content are reduced in 4-month old iPLA ${ }_{2} \beta^{-I-}$ mice $[4,21]$, but we found no significant difference between genotypes in brain expression of these acyltransferases or of 15-LOX, which is also involved in DHA metabolism [38].

Reduced DHA incorporation from plasma into brain in $\mathrm{iPLA}_{2} \beta^{-1-}$ mice would be expected to reduce production of DHA-derived resolvin D1 and neuroprotectin D1, which have potent anti-inflammatory properties [39, 40]. DHA also may reduce pro-inflammatory AA metabolite production by inhibiting COX-2 $[1,41]$, consistent with the suggested role of $\operatorname{iPLA}_{2} \beta$ in regulating prostaglandin $E_{2}$ formation [7]. It would be worthwhile to test whether 
A

CD11b mRNA
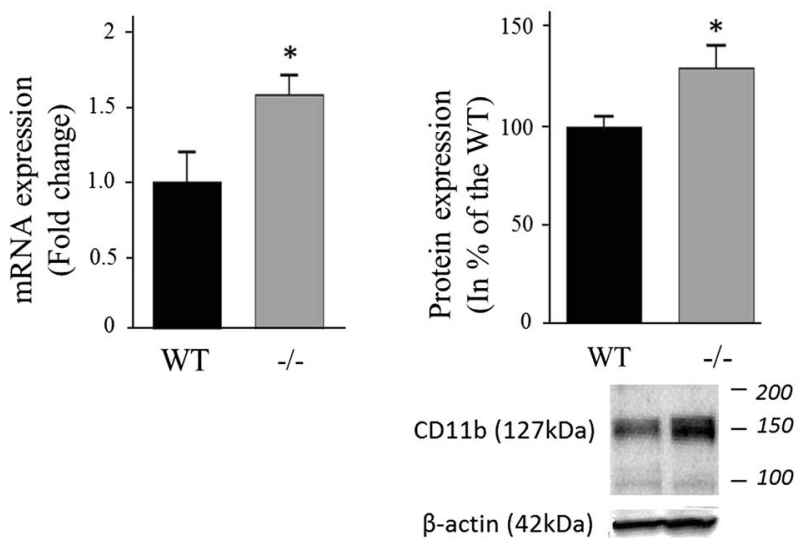

C Synaptophysin protein

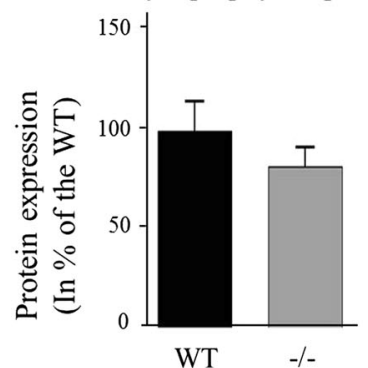

Synaptophysin (37kDa)

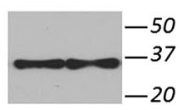

$\beta-\operatorname{actin}(42 \mathrm{kDa})$

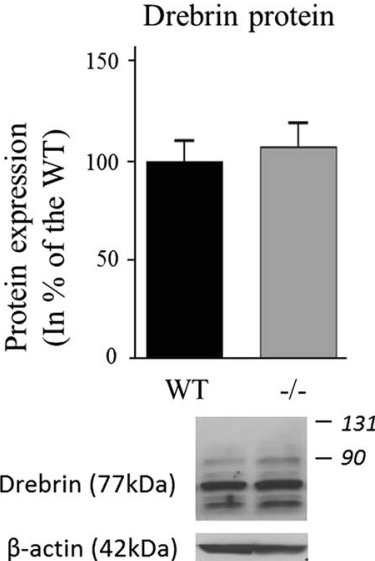

$\beta$-actin $(42 \mathrm{kDa})$
B GFAP MRNA

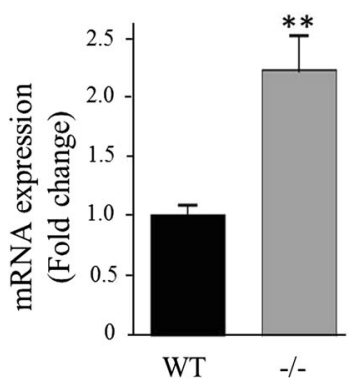

WT $\quad-/-$

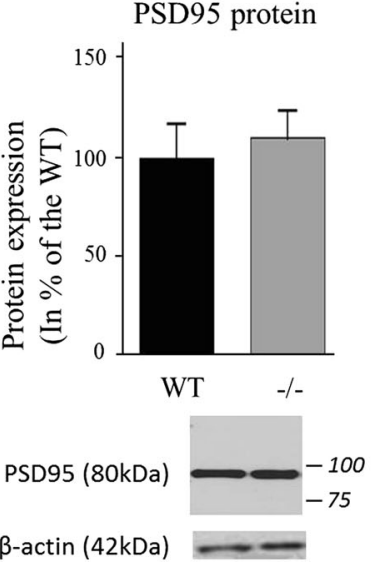

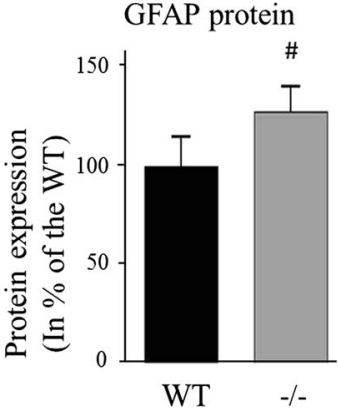

GFAP (50kDa)

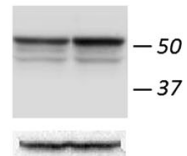

$\beta$-actin (42kDa)

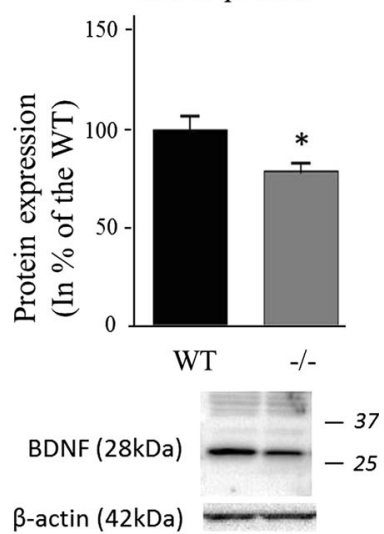

Fig. 6 Expression of microglial, astrocytic, synaptic markers and BNDF in WT and $\mathrm{iPLA}_{2} \beta^{-1-}$ mice. mRNA was quantified in duplicate with Taqman ${ }^{\circledR}$ RT-PCR using the $\Delta \Delta \mathrm{Ct}$ method and normalization to $18 S$ expression. Results are expressed as mean \pm SEM $(\mathrm{n}=8)$. CD11b, synaptophysin and PSD-95 expression was measured in brain membrane fractions by Western blot and GFAP, drebrin and BDNF were quantified in the cytosol. Results are

$\mathrm{iPLA}_{2} \beta^{-/-}$mice have reduced DHA-derived metabolites and increased AA-derived products in future studies.

The elevated brain levels in iPLA ${ }_{2} \beta^{-1-}$ mice of $\mathrm{SPLA}_{2}-\mathrm{V}$ mRNA and P-cPLA ${ }_{2} \alpha$ protein, which represents the catalytically active form of $\mathrm{CPLA}_{2} \alpha$, suggests compensatory upregulation of brain AA metabolism [42]. Upregulation also occurs when DHA metabolism is reduced by dietary n-3 fatty acid deprivation [43]. Increased P-cPLA ${ }_{2} \alpha$ protein suggests accelerated post-translational phosphorylation of $\mathrm{CPLA}_{2} \alpha$ serine residues [44]. COX-2 expression was reduced, although it was reported to be elevated at 4 months [21]. Expression of COX-1, which can be coupled to iPLA ${ }_{2} \beta$ [45], was unchanged.

Similar protein levels of drebrin, PSD95, synaptophysin and DAT in the 15-20 month old $\mathrm{iPLA}_{2} \beta^{-1-}$ and WT mice suggest absence of synaptic loss. On the other hand, presynaptic DAT protein is reduced in Parkinson normalized to $\beta$-actin expression (representative immunoblot is displayed) and expressed as \% of the WT mice as mean \pm SEM $\left(\mathrm{n}=8\right.$ except $\mathrm{n}=7$ for BDNF in WT and $\mathrm{iPLA}_{2} \beta^{-/-}$, respectively due to the removal of an outlier value of 222 and sample loss). Numbers in italics indicate molecular weight markers (in $\mathrm{kDa}$ ). $* P<0.05,{ }^{* *} P<0.01$ ( $t$ test) and \#0.5 $<d>0.8$ (Cohen's $d$ test)

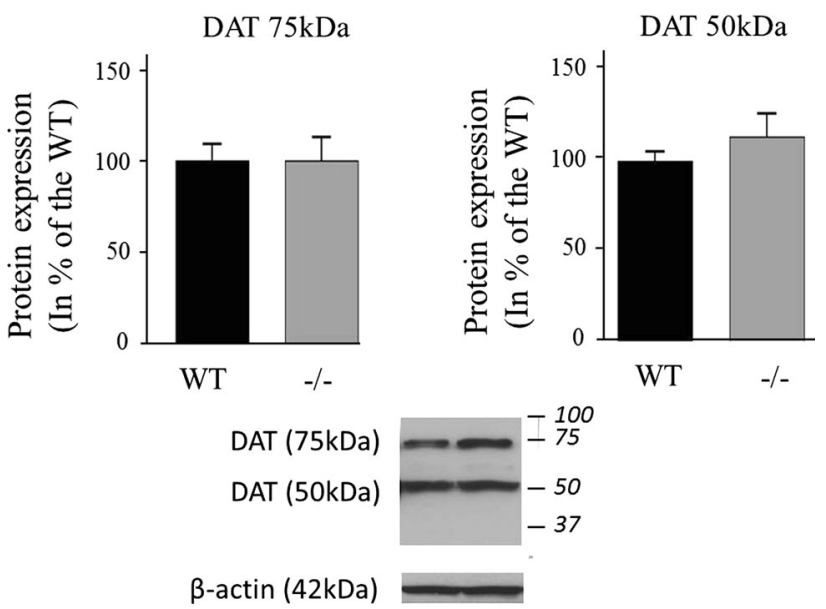

Fig. 7 Expression of DAT in WT and $\mathrm{iPLA}_{2} \beta^{-1-}$ mice. DAT protein was measured in brain membrane fractions by Western blot. Results are normalized to $\beta$-actin expression (representative immunoblot is displayed) and expressed as \% of WT mice as mean \pm SEM $(\mathrm{n}=8)$. Numbers in italics indicate molecular weight markers (in $\mathrm{kDa}$ ) 
Fig. 8 Expression of $\alpha$ synuclein (a), PINK1 (b) and Parkin (c) in WT and iPLA $_{2} \beta^{-1-}$ mice. mRNA was quantified in duplicate with Taqman ${ }^{\circledR}$ RT-PCR using the $\Delta \Delta \mathrm{Ct}$ method and normalization to $18 S$ expression. Results are expressed as mean \pm SEM $(\mathrm{n}=8) \cdot \boldsymbol{\alpha}$-synuclein (a) and PINK1 (b) were quantified in the cytosolic fraction. Both cytosolic (c-i) and membrane (c-ii) parkin protein levels were determined. After normalization to $\beta$-actin expression (representative immunoblot is displayed), results are expressed as $\%$ of the WT mice as mean \pm SEM $(\mathrm{n}=8, \mathrm{n}=7$ for $\alpha$-synuclein WT (outlier value of 241 was removed) and for $\mathrm{n}=7$ for Pink1 due to an unquantifiable signal). Numbers in italics indicate molecular weight markers (in $\mathrm{kDa}$ ). $* P<0.05$ ( $t$ test $)$
A $\quad \alpha$-synuclein mRNA
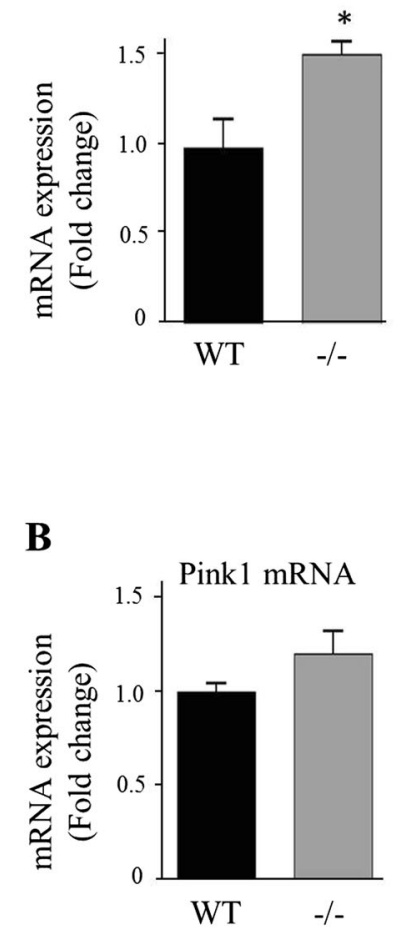

C

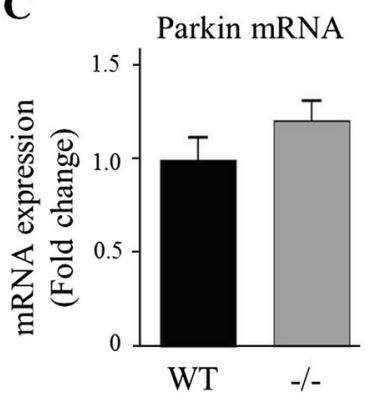

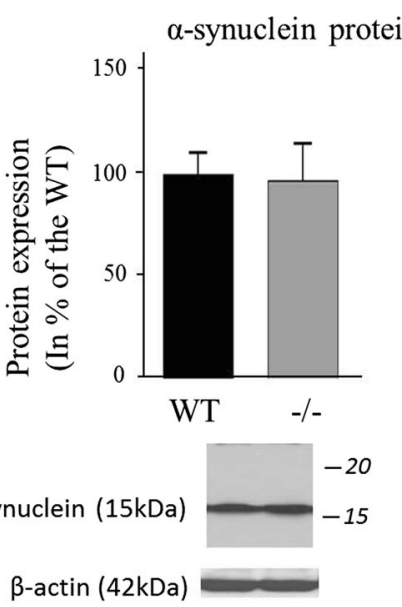

Pink1 protein

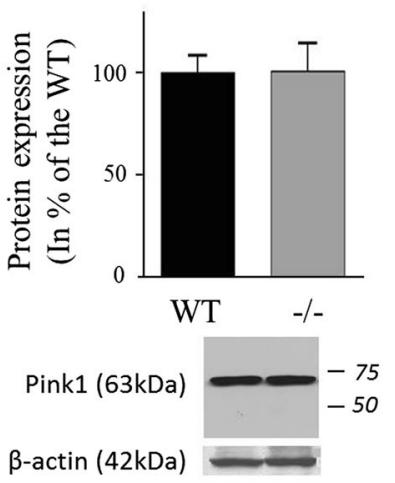

Parkin protein
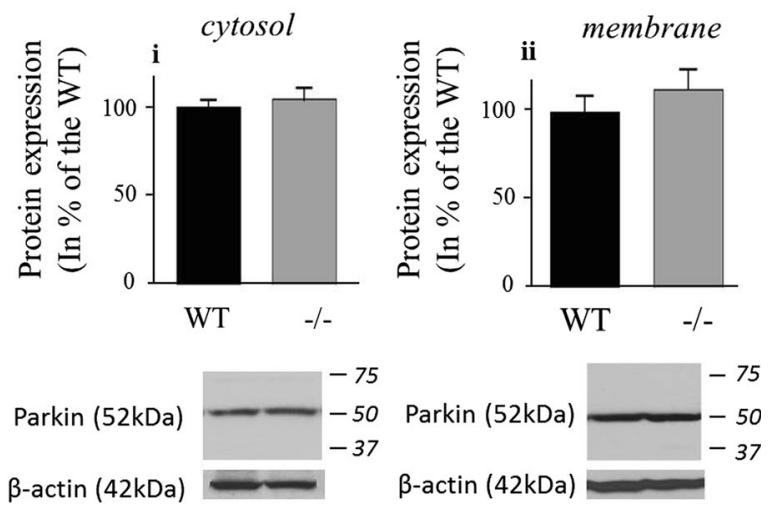

disease [46], and following ablation of the substantia nigra in rodent models of Parkinson disease [47]. Thus, at 15-20 months, the model does not have all the classical features of Parkinson disease. This also applies to the absence of differences in expression of Parkin (Park2) [48] and of Pink1 (Park6) [49], which regulate mitochondrial integrity [50]. Regional changes potentially identifiable by immunocytochemistry cannot yet be excluded, especially in the substantia nigra, which is specifically impacted by dopaminergic neuronal loss in Parkinson disease.
Activated microglia produce NO via iNOS, reactive oxygen species, and pro-inflammatory cytokines that might contribute to brain pathology in Parkinson disease [51, 52]. Reduced BDNF expression in the older $\mathrm{PLA}_{2} \beta^{-/-}$mice also suggests increased susceptibility to neuronal death [53], which is observed in the substantia nigra of Parkinson disease patients [54].

Brain $\alpha$-synuclein mRNA was increased in the older iPLA $_{2} \beta^{-1-}$ mice, consistent with reported $\alpha$-synucleinpositive spheroids in the striatum of $\mathrm{iPLA}_{2} \beta^{-/-}$mice [16]. Alpha-synuclein can activate glia [55] and is thought to 
promote a self-perpetuating neurotoxic process in Parkinson disease [52]. It impacts PUFA metabolism [56] and may bind long chain fatty acids [57]. On the other hand, dietary DHA supplementation was reported to promote $\alpha$ synuclein accumulation in a mouse model of Parkinson disease [58].

An iPLA $\mathrm{A}_{2} \beta$ preference for DHA-containing phospholipid substrates is well established $[4,6,7,59]$, but esterified AA also can be hydrolyzed by iPLA ${ }_{2} \beta[60,61]$. Thus, an iPLA $A_{2} \beta$ deficiency also might influence AA release and eicosanoid formation.

In summary, life-long distortion of brain DHA content and metabolism in $\mathrm{iPLA}_{2} \beta^{-1-}$ mice is associated with lateappearing motor disturbances accompanied by microglial and astrocytic activation, disturbed expression of enzymes involved in arachidonic acid metabolism, loss of neuroprotective BDNF, and increased neuroinflammatory cytokine expression. Using these biomarkers, efficacy of dietary interventions or suppressors of oxidative stress might be tested on disease progression in this animal model, which mimics many aspects of human progressive motor diseases, including Parkinson disease.

Acknowledgments The authors thank the NIH Fellow Editorial Board and Ms. Mairi Stevens for editorial assistance and Dr. Dede Greenstein for statistical support. Research was supported by the Intramural Research Program of the National Institute on Aging and, for JT, by United States Public Health Service Grants R37-DK34388, P41-RR00954, P60-DK20579, and P30-DK56341.

Conflict of interest Authors declare no competing financial interests.

\section{References}

1. Corey EJ, Shih C, Cashman JR (1983) Docosahexaenoic acid is a strong inhibitor of prostaglandin but not leukotriene biosynthesis. Proc Natl Acad Sci USA 80(12):3581-3584

2. Yavin E, Brand A, Green P (2002) Docosahexaenoic acid abundance in the brain: a biodevice to combat oxidative stress. Nutr Neurosci 5(3):149-157

3. Balsinde J, Balboa MA (2005) Cellular regulation and proposed biological functions of group VIA calcium-independent phospholipase A2 in activated cells. Cell Signal 17(9):1052-1062

4. Basselin M, Rosa AO, Ramadan E, Cheon Y, Chang L, Chen M, Greenstein D, Wohltmann M, Turk J, Rapoport SI (2010) Imaging decreased brain docosahexaenoic acid metabolism and signaling in iPLA(2)beta (VIA)-deficient mice. J Lipid Res 51(11):3166-3173

5. Domenichiello AF, Chen CT, Trepanier MO, Stavro PM, Bazinet RP (2014) Whole body synthesis rates of DHA from alpha-linolenic acid are greater than brain DHA accretion and uptake rates in adult rats. J Lipid Res 55(1):62-74

6. Yang HC, Mosior M, Ni B, Dennis EA (1999) Regional distribution, ontogeny, purification, and characterization of the $\mathrm{Ca} 2+$-independent phospholipase A2 from rat brain. J Neurochem 73(3): 1278-1287

7. Strokin M, Sergeeva M, Reiser G (2007) Prostaglandin synthesis in rat brain astrocytes is under the control of the n-3 docosahexaenoic acid, released by group VIB calcium-independent phospholipase A2. J Neurochem 102(6):1771-1782

8. Balboa MA, Varela-Nieto I, Killermann Lucas K, Dennis EA (2002) Expression and function of phospholipase $A(2)$ in brain. FEBS Lett 531(1):12-17

9. Nardocci N, Zorzi G, Farina L, Binelli S, Scaioli W, Ciano C, Verga L, Angelini L, Savoiardo M, Bugiani O (1999) Infantile neuroaxonal dystrophy: clinical spectrum and diagnostic criteria. Neurology 52(7):1472-1478

10. Gregory A, Westaway SK, Holm IE, Kotzbauer PT, Hogarth P, Sonek S, Coryell JC, Nguyen TM, Nardocci N, Zorzi G, Rodriguez D, Desguerre I, Bertini E, Simonati A, Levinson B, Dias C, Barbot C, Carrilho I, Santos M, Malik I, Gitschier J, Hayflick SJ (2008) Neurodegeneration associated with genetic defects in phospholipase A(2). Neurology 71(18):1402-1409

11. Morgan NV, Westaway SK, Morton JE, Gregory A, Gissen P, Sonek S, Cangul H, Coryell J, Canham N, Nardocci N, Zorzi G, Pasha S, Rodriguez D, Desguerre I, Mubaidin A, Bertini E, Trembath RC, Simonati A, Schanen C, Johnson CA, Levinson B, Woods CG, Wilmot B, Kramer P, Gitschier J, Maher ER, Hayflick SJ (2006) PLA2G6, encoding a phospholipase A2, is mutated in neurodegenerative disorders with high brain iron. Nat Genet 38(7):752-754

12. Yoshino H, Tomiyama H, Tachibana N, Ogaki K, Li Y, Funayama M, Hashimoto T, Takashima S, Hattori N (2010) Phenotypic spectrum of patients with PLA2G6 mutation and PARK14-linked parkinsonism. Neurology 75(15):1356-1361

13. Lu CS, Lai SC, Wu RM, Weng YH, Huang CL, Chen RS, Chang HC, Wu-Chou YH, Yeh TH (2012) PLA2G6 mutations in PARK14-linked young-onset parkinsonism and sporadic Parkinson's disease. Am J Med Genet B Neuropsychiatr Genet 159B(2):183-191

14. Paisan-Ruiz C, Li A, Schneider SA, Holton JL, Johnson R, Kidd D, Chataway J, Bhatia KP, Lees AJ, Hardy J, Revesz T, Houlden H (2012) Widespread Lewy body and tau accumulation in childhood and adult onset dystonia-parkinsonism cases with PLA2G6 mutations. Neurobiol Aging 33(4):814-823

15. Gui YX, Xu ZP, Wen L, Liu HM, Zhao JJ, Hu XY (2013) Four novel rare mutations of PLA2G6 in Chinese population with Parkinson's disease. Parkinsonism Relat Disord 19(1): $21-26$

16. Malik I, Turk J, Mancuso DJ, Montier L, Wohltmann M, Wozniak DF, Schmidt RE, Gross RW, Kotzbauer PT (2008) Disrupted membrane homeostasis and accumulation of ubiquitinated proteins in a mouse model of infantile neuroaxonal dystrophy caused by PLA2G6 mutations. Am J Pathol 172(2):406-416

17. Zhao Z, Zhang X, Zhao C, Choi J, Shi J, Song K, Turk J, Ma ZA (2010) Protection of pancreatic beta-cells by group VIA phospholipase $\mathrm{A}(2)$-mediated repair of mitochondrial membrane peroxidation. Endocrinology 151(7):3038-3048

18. Lee LY, Ong WY, Farooqui AA, Burgunder JM (2007) Role of calcium-independent phospholipase A2 in cortex striatum thalamus cortex circuitry-enzyme inhibition causes vacuous chewing movements in rats. Psychopharmacology 195(3):387-395

19. Shinzawa K, Sumi H, Ikawa M, Matsuoka Y, Okabe M, Sakoda S, Tsujimoto Y (2008) Neuroaxonal dystrophy caused by group VIA phospholipase A2 deficiency in mice: a model of human neurodegenerative disease. J Neurosci 28(9):2212-2220

20. Zhao Z, Wang J, Zhao C, Bi W, Yue Z, Ma ZA (2011) Genetic ablation of PLA2G6 in mice leads to cerebellar atrophy characterized by Purkinje cell loss and glial cell activation. Plos One 6(10):e26991

21. Cheon Y, Kim HW, Igarashi M, Modi HR, Chang L, Ma K, Greenstein D, Wohltmann M, Turk J, Rapoport SI and Taha AY (2012) Disturbed brain phospholipid and docosahexaenoic acid metabolism in calcium-independent phospholipase A(2)-VIA 
(iPLA(2)beta)-knockout mice. Biochim Biophys Acta 1821(9): 1278-1286

22. Rapoport SI (2008) Brain arachidonic and docosahexaenoic acid cascades are selectively altered by drugs, diet and disease. Prostaglandins Leukot Essent Fatty Acid 79(3-5):153-156

23. Bao S, Miller DJ, Ma Z, Wohltmann M, Eng G, Ramanadham S, Moley K, Turk J (2004) Male mice that do not express group VIA phospholipase A2 produce spermatozoa with impaired motility and have greatly reduced fertility. J Biol Chem 279(37): 38194-38200

24. Bradford MM (1976) A rapid and sensitive method for the quantitation of microgram quantities of protein utilizing the principle of protein-dye binding. Anal Biochem 72:248-254

25. Abramoff MD, Magalhaes PJ, Ram SJ (2004) Image Processing with ImageJ. Biophotonics Int 11(7):36-42

26. Cohen J (1992) A power primer. Psychol Bull 112(1):155-159

27. Rock RB, Gekker G, Hu S, Sheng WS, Cheeran M, Lokensgard JR, Peterson PK (2004) Role of microglia in central nervous system infections. Clin Microbiol Rev 17(4):942-964

28. Chao J, Leung Y, Wang M, Chang RC (2012) Nutraceuticals and their preventive or potential therapeutic value in Parkinson's disease. Nutr Rev 70(7):373-386

29. Sutachan JJ, Casas Z, Albarracin SL, Stab BR 2nd, Samudio I, Gonzalez J, Morales L, Barreto GE (2012) Cellular and molecular mechanisms of antioxidants in Parkinson's disease. Nutr Neurosci $15(3): 120-126$

30. Igarashi M, Gao F, Kim HW, Ma K, Bell JM, Rapoport SI (2009) Dietary n-6 PUFA deprivation for 15 weeks reduces arachidonic acid concentrations while increasing n-3 PUFA concentrations in organs of post-weaning male rats. Biochim Biophys Acta 1791(2):132-139

31. Kim HW, Rao JS, Rapoport SI, Igarashi M (2011) Dietary n-6 PUFA deprivation downregulates arachidonate but upregulates docosahexaenoate metabolizing enzymes in rat brain. Biochim Biophys Acta 1811(2):111-117

32. Ramsden CE, Mann JD, Faurot KR, Lynch C, Imam ST, MacIntosh BA, Hibbeln JR, Loewke J, Smith S, Coble R, Suchindran C, Gaylord SA (2011) Low omega-6 versus low omega-6 plus high omega-3 dietary intervention for chronic daily headache: protocol for a randomized clinical trial. Trials 12:97

33. Marszalek JR, Kitidis C, Dirusso CC, Lodish HF (2005) Longchain acyl-CoA synthetase 6 preferentially promotes DHA metabolism. J Biol Chem 280(11):10817-10826

34. Yamashita A, Sugiura T, Waku K (1997) Acyltransferases and transacylases involved in fatty acid remodeling of phospholipids and metabolism of bioactive lipids in mammalian cells. J Biochem 122(1):1-16

35. Gijon MA, Riekhof WR, Zarini S, Murphy RC, Voelker DR (2008) Lysophospholipid acyltransferases and arachidonate recycling in human neutrophils. J Biol Chem 283(44):30235-30245

36. DeGeorge JJ, Nariai T, Yamazaki S, Williams WM, Rapoport SI (1991) Arecoline-stimulated brain incorporation of intravenously administered fatty acids in unanesthetized rats. J Neurochem 56(1):352-355

37. Cao J, Shan D, Revett T, Li D, Wu L, Liu W, Tobin JF, Gimeno RE (2008) Molecular identification of a novel mammalian brain isoform of acyl-CoA:lysophospholipid acyltransferase with prominent ethanolamine lysophospholipid acylating activity, LPEAT2. J Biol Chem 283(27):19049-19057

38. Lukiw WJ, Cui JG, Marcheselli VL, Bodker M, Botkjaer A, Gotlinger K, Serhan CN, Bazan NG (2005) A role for docosahexaenoic acid-derived neuroprotectin D1 in neural cell survival and Alzheimer disease. J Clin Invest 115(10):2774-2783

39. Hong S, Gronert K, Devchand PR, Moussignac RL, Serhan CN (2003) Novel docosatrienes and 17S-resolvins generated from docosahexaenoic acid in murine brain, human blood, and glial cells autacoids in anti-inflammation. J Biol Chem 278(17): 14677-14687

40. Serhan CN, Yacoubian S, Yang R (2008) Anti-inflammatory and proresolving lipid mediators. Annu Rev Pathol 3:279-312

41. Swamy MV, Cooma I, Patlolla JM, Simi B, Reddy BS, Rao CV (2004) Modulation of cyclooxygenase-2 activities by the combined action of celecoxib and decosahexaenoic acid: novel strategies for colon cancer prevention and treatment. Mol Cancer Ther 3(2):215-221

42. Clark JD, Lin LL, Kriz RW, Ramesha CS, Sultzman LA, Lin AY, Milona N, Knopf JL (1991) A novel arachidonic acid-selective cytosolic PLA2 contains a $\mathrm{Ca}(2+)$-dependent translocation domain with homology to PKC and GAP. Cell 65(6):1043-1051

43. Kim HW, Rao JS, Rapoport SI, Igarashi M (2011) Regulation of rat brain polyunsaturated fatty acid (PUFA) metabolism during graded dietary n-3 PUFA deprivation. Prostaglandins Leukot Essent Fatty Acids 85(6):361-368

44. Buschbeck M, Ghomashchi F, Gelb MH, Watson SP, BorschHaubold AG (1999) Stress stimuli increase calcium-induced arachidonic acid release through phosphorylation of cytosolic phospholipase A2. Biochem J 344(Pt 2):359-366

45. Murakami M, Kambe T, Shimbara S, Kudo I (1999) Functional coupling between various phospholipase A2 s and cyclooxygenases in immediate and delayed prostanoid biosynthetic pathways. J Biol Chem 274(5):3103-3115

46. Scherfler C, Schwarz J, Antonini A, Grosset D, Valldeoriola F, Marek K, Oertel W, Tolosa E, Lees AJ, Poewe W (2007) Role of DAT-SPECT in the diagnostic work up of parkinsonism. Mov Disord 22(9): 1229-1238

47. Bhattacharjee AK, Meister LM, Chang L, Bazinet RP, White L, Rapoport SI (2007) In vivo imaging of disturbed pre- and postsynaptic dopaminergic signaling via arachidonic acid in a rat model of Parkinson's disease. NeuroImage 37(4):1112-1121

48. Kitada T, Asakawa S, Hattori N, Matsumine H, Yamamura Y, Minoshima S, Yokochi M, Mizuno Y, Shimizu N (1998) Mutations in the parkin gene cause autosomal recessive juvenile parkinsonism. Nature 392(6676):605-608

49. Valente EM, Abou-Sleiman PM, Caputo V, Muqit MM, Harvey K, Gispert S, Ali Z, Del Turco D, Bentivoglio AR, Healy DG, Albanese A, Nussbaum R, Gonzalez-Maldonado R, Deller T, Salvi S, Cortelli P, Gilks WP, Latchman DS, Harvey RJ, Dallapiccola B, Auburger G, Wood NW (2004) Hereditary early-onset Parkinson's disease caused by mutations in PINK1. Science 304(5674): 1158-1160

50. Pilsl A, Winklhofer KF (2012) Parkin, PINK1 and mitochondrial integrity: emerging concepts of mitochondrial dysfunction in Parkinson's disease. Acta Neuropathol 123(2):173-188

51. Hirsch EC, Breidert T, Rousselet E, Hunot S, Hartmann A, Michel PP (2003) The role of glial reaction and inflammation in Parkinson's disease. Ann NY Acad Sci 991:214-228

52. Block ML, Zecca L, Hong JS (2007) Microglia-mediated neurotoxicity: uncovering the molecular mechanisms. Nat Rev Neurosci 8(1):57-69

53. Barde YA (1994) Neurotrophins: a family of proteins supporting the survival of neurons. Prog Clin Biol Res 390:45-56

54. Howells DW, Porritt MJ, Wong JY, Batchelor PE, Kalnins R, Hughes AJ, Donnan GA (2000) Reduced BDNF mRNA expression in the Parkinson's disease substantia nigra. Exp Neurol 166(1):127-135

55. Zhang W, Wang T, Pei Z, Miller DS, Wu X, Block ML, Wilson B, Zhou Y, Hong JS, Zhang J (2005) Aggregated alpha-synuclein activates microglia: a process leading to disease progression in Parkinson's disease. FASEB J 19(6):533-542

56. Golovko MY, Rosenberger TA, Feddersen S, Faergeman NJ, Murphy EJ (2007) Alpha-synuclein gene ablation increases docosahexaenoic acid incorporation and turnover in brain phospholipids. J Neurochem 101(1):201-211 
57. Golovko MY, Rosenberger TA, Faergeman NJ, Feddersen S, Cole NB, Pribill I, Berger J, Nussbaum RL, Murphy EJ (2006) Acyl-CoA synthetase activity links wild-type but not mutant alpha-synuclein to brain arachidonate metabolism. Biochemistry 45(22):6956-6966

58. Yakunin E, Loeb V, Kisos H, Biala Y, Yehuda S, Yaari Y, Selkoe DJ, Sharon R (2012) Alpha-synuclein neuropathology is controlled by nuclear hormone receptors and enhanced by docosahexaenoic acid in a mouse model for Parkinson's disease. Brain Pathol 22(3):280-294

59. Ramadan E, Rosa AO, Chang L, Chen M, Rapoport SI, Basselin M (2010) Extracellular-derived calcium does not initiate in vivo neurotransmission involving docosahexaenoic acid. J Lipid Res 51(8):2334-2340

60. Lehman JJ, Brown KA, Ramanadham S, Turk J, Gross RW (1993) Arachidonic acid release from aortic smooth muscle cells induced by [Arg8]vasopressin is largely mediated by calcium-independent phospholipase A2. J Biol Chem 268(28): 20713-20716

61. Wolf MJ, Gross RW (1996) Expression, purification, and kinetic characterization of a recombinant $80-\mathrm{kDa}$ intracellular calcium-independent phospholipase A2. J Biol Chem 271(48): 30879-30885 